\title{
Correction to: A New Species of Dynamine Hübner, [1819] (Lepidoptera: Nymphalidae: Biblidinae) from the Atlantic Forest in Southeastern Brazil
}

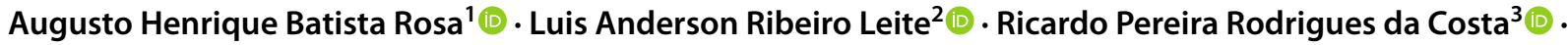 \\ André Victor Lucci Freitas ${ }^{1}$ (1)
}

Accepted: 13 September 2021 / Published online: 1 October 2021

(c) Sociedade Entomológica do Brasil 2021

\section{Correction to: Neotropical Entomology \\ https://doi.org/10.1007/s13744-021-00898-8}

Due to unfortunate events, the species identification year in the title is incorrect as it should have stated [1819]. In addition, the ZooBank registration is missing. The correct title as well as the ZooBank data is published here.

ZooBank Registration The species Dynamine sideria Rosa \& Freitas, 2021 (https://doi.org/10.1007/s13744-021-00898-8) is registered with ZooBank under LSID 952A822F-7F2D-4847-B95A-353706DFCC10

Publisher's Note Springer Nature remains neutral with regard to jurisdictional claims in published maps and institutional affiliations.

The online version of the original article can be found at https:// doi.org/10.1007/s13744-021-00898-8

André Victor Lucci Freitas

baku@unicamp.br

1 Depto de Biologia Animal and Museu de Diversidade Biológica, Depto de Biologia Animal and Museu de Zoologia, Instituto de Biologia, Universidade Estadual de Campinas - UNICAMP, Campinas, São Paulo, Brazil

2 Depto de Zoologia, Lab de Estudos de Lepidoptera Neotropical, Univ Federal do Paraná - UFPR, Curitiba, Paraná, Brazil

3 São Paulo, Brazil 